\title{
Isolation and Partial Nucleic Acid Characterization of a New Isolate of Potato virus $V$ with Distinct Biological and Serological Properties
}

\author{
P. J. Shiel, Department of Plant, Soil and Entomological Sciences, University of Idaho, Moscow, ID 83844; \\ L. Miller and S. A. Slack, Department of Plant Pathology, Cornell University, Ithaca, NY 14853; and P. H. Berger, \\ Department of Plant, Soil and Entomological Sciences, University of Idaho, Moscow, ID 83844
}

\begin{abstract}
Shiel, P. J., Miller, L., Slack, S. A., and Berger, P. H. 2004. Isolation and partial nucleic acid characterization of a new isolate of Potato virus $V$ with distinct biological and serological properties. Plant Dis. 88:368-372.

In vitro cultures of potato (Solanum tuberosum cv. Papa Amarillo) were imported into the United States and were subjected to routine pathogen screening for newly introduced varieties. These cultures indexed positive for several of the six viruses tested and thus were treated using standard methods for eliminating viruses in in vitro cultures. Although the therapy apparently freed the potato of the tested viruses, some of the cultures continued to exhibit mosaic symptoms when planted in the greenhouse. When examined by electron microscopy, these plants contained flexuous rods. Tested samples did not index positive with any potato virus-specific polyclonal antisera but reacted with the "universal" potyvirus monoclonal antibody. These results indicated that these samples were likely infected with an as yet undescribed potyvirus. Further investigation indicated that this virus is a new strain of Potato virus $V(\mathrm{PVV})$ that is serologically distinct from the common strain. This is the first description of a distinct strain of PVV. This particular strain has diverged sufficiently from other isolates of PVV to no longer be detectable by some commonly used antisera, and therefore is a concern for the future restriction of PVV spread into regions of the world where it is not currently present.
\end{abstract}

Potato virus $V$ (PVV) is a potatoinfecting potyvirus that is serologically related to a number of other potyviruses, particularly Potato virus $Y^{\mathrm{C}} \quad\left(\mathrm{PVY}^{\mathrm{C}}\right)$ $(4,8,12)$, Peru tomato mosaic virus (PTV) (7), and Wild potato mosaic virus (2). It was first described as a distinct potyvirus in 1984 (8). Although it has been suggested that PVV is a strain of PTV, serological analysis showed that PVV is distinct (11). The genome of PVV is distinguished from that of PVY and other potyviruses closely related to PVY because of its unusually long $3^{\prime}$-untranslated region, which is 446 nucleotides long (not including the poly-A tail) based on sequences currently available in GenBank. No strains of PVV have yet been differentiated by biological or serological proper-

Corresponding author: P. H. Berger

E-mail: Philip.H.Berger@aphis.usda.gov

Current address of S. A. Slack: OARDC, Wooster, OH 44691.

Current address of P. H. Berger: Center for Plant Health Science and Technology, Suite 2500, 1017 Main Campus Dr., Raleigh, NC 27606.

This sequence has been deposited into GenBank as accession AY521595.

Accepted for publication 12 November 2003.

Publication no. D-2004-0116-01R

(C) 2004 The American Phytopathological Society ties, or by RNA sequence comparisons (3). PVV generally only causes mild symptoms in potato and has so far only been reported in the Andean region of South America and in Northwestern Europe (2). European isolates that have been characterized appear to have little genetic variability and are thought to all belong to the same strain (11).

In May of 1997, an in vitro culture of potato (Solanum tuberosum cv. Papa Amarillo "Yellow potato") was received by the Department of Plant Pathology at Cornell University from The Seed Savers Exchange (Decorah, IA). The plant material was entered into the standard pathogen screening for new varieties entering the program, which included testing by enzyme-linked immunosorbent assay (ELISA) for six common viruses that infect potato. Plants that showed initial infection by these viruses would be entered into a standard virus elimination therapy conducted by the project (13). Plantlets that went through this program could then be retested to determine if the viruses were eliminated by the therapy. This particular potato clone did not survive the 4-week standard virus elimination therapy, so plantlets were removed from the heat after approximately 2 weeks. Several treated lines that survived therapy tested negative in ELISA for the six previously mentioned viruses. However, greenhouse-grown plants of these treated potato tissue cultures displayed mosaic symptoms as soon as the leaves were large enough to see symptoms, even though they continued to test negative in ELISA for the six viruses routinely screened by the program. From these plants, several leaf dip preparations examined by transmission electron microscopy (TEM) contained flexuous rod-like particles that resembled potyviruses. One of these potato lines, labeled PA-4 was selected for further study. Another line, PA-10 of the same variety, also tested negative in ELISA for the six previously mentioned viruses. However, greenhousegrown plants of this line did not display mosaic symptoms. Flexuous rod-like particles were not observed when leaf dip preparations of this line were examined by TEM. Therefore, PA-10 was also examined as a potential virus-free line in the further study of the PA-4 line.

\section{MATERIALS AND METHODS}

Virus source and serological assays. In vitro cultures of potato cv. Papa Amarillo, "Yellow potato" were received at Cornell University, Department of Plant Pathology, from The Seed Savers Exchange (Decorah, IA). The plant material was entered into the standard pathogen screening for new varieties entering the program, which included testing by ELISA for six viruses, Potato virus X, PVY, Potato leafroll virus, Potato virus $S$, Potato virus A (PVA), and Potato virus $M$ (PVM). The clones were then subjected to the standard virus elimination therapy conducted by the project (13). Very small nodes $(\sim 1.5 \mathrm{~mm})$ were excised and established on a modified growth medium containing an antiviral chemical (ribavirin) (ICN Biomedicals, Aurora, OH). Established plantlets were moved from room temperature to a growth chamber and subjected to a heat regimen for 4 weeks (13).

Some of the particular potato clones did not survive standard virus elimination therapy, so plantlets were removed from the heat after approximately 2 weeks and then were grown in the greenhouse under 18-h day length using supplemental lighting with temperatures between 24 and $27^{\circ} \mathrm{C}$ during the day and 18 and $21^{\circ} \mathrm{C}$ at night.

The PA-4 potato clone was initially tested for the presence of 16 potyviruses by Agdia, Inc. (Elkhart, IN) using their standard ELISA procedures. The viruses tested by this procedure include Lettuce 
mosaic virus, Papaya ringspot virus, PVA, Soybean mosaic virus, Watermelon mosaic virus 2, Banana bract mosaic virus, Johnsongrass mosaic virus, Maize dwarf mosaic virus, Plum pox virus, PVY, Sugarcane mosaic virus - MDMV-B, Tobacco etch virus, Tobacco vein mottling virus, Turnip mosaic virus, Zucchini yellow mosaic virus, and PVV. In addition, the potato sample was tested at the same time by Agdia with the POTY1 monoclonal antibody that has been shown to react with nearly all known potyviruses (9). Additional testing for PVV of both the PA-4 sample and PA-10 was performed by two other independent testing laboratories to determine serological characteristics of the virus isolate. STA Laboratories, Inc., Longmont, $\mathrm{CO}$, tested the samples by ELISA using the BIOREBA polyclonal antibodies for PVV (Bioreba AG, Switzerland), and Phyto Diagnostics (Vancouver, $\mathrm{BC}$, Canada) tested the samples by ELISA using the Agden, Ltd. (U.K., a division of Neogen, Inc., Lansing, MI) supplied monoclonal antibody and monoclonal alkaline-phosphatase conjugate. These assays were performed along with positive controls supplied by these companies for comparison.

Host range. The Papa Amarillo potato line that contained the putative virus infection, and a virus-free control, were used as inoculum for inoculation and host range studies. Leaf tissue of the PA-4 line testing positive in ELISA was ground with a sterilized mortar and pestle with $0.05 \mathrm{M}$ sodium phosphate buffer, $\mathrm{pH} 7.0$, containing $0.02 \mathrm{M}$ sodium sulfite. Five volumes of buffer was added to the fresh tissue (wt/vol). Leaf tissue of adjacently grown potatoes of the line PA-10 was used as a negative control.

Initial host range studies were conducted using two plants each of tobacco (Nicotiana tabacum cvs. Xanthi and Burley 21), Chenopodium quinoa, C. amaranticolor, $N$. benthamiana (the standard plant quarantine station isolates were kindly provided by Walt Kaiser, formerly of the USDA Western Region Plant Introduction Station, Central Ferry, WA), and two varieties of tomato (Lycopersicon esculentum cvs. Campbell Soup and Marglobe, also provided by Walt Kaiser). All plants were grown in the greenhouse under 18-h day length using supplemental lighting with temperatures between 24 and $27^{\circ} \mathrm{C}$ during the day and 18 and $21^{\circ} \mathrm{C}$ at night.

Inoculation of plants was done using the PA-4 line (virus infected), the PA-10 line (virus free), and tissue from $\mathrm{PVY}^{\mathrm{O}}$ infected tobacco with a total of two plants for each inoculation treatment. Potential infection of each plant was confirmed by back-inoculation onto two plants of $N$. benthamiana for each assay plant. Additional hosts were subsequently tested, and included potato cv. Russet Burbank (certified virus-free explants from the University of Idaho Nuclear Potato Seed Program, Moscow, ID, kindly provided by Loraleta Ewing, Program Coordinator) and Papa Amarillo PA-10, tomato (cv. Rutgers), Datura stramonium, and D. metel (provided by Walt Kaiser). All samples were back-inoculated onto two plants each of $N$. benthamiana for each assay plant 14 days after inoculation. Repeated attempts to inoculate the Datura species, tobacco, and 'Russet Burbank' potato (using N. benthamiana and PA-10 line as positive controls) were conducted for a total of four attempts for each of these plant species.

Purification of the PA-4 virus. Purification of virus was performed using a modification of standard potyvirus purification protocols (1). Leaf tissue from $N$. benthamiana plants inoculated (as described above) with the PA-4 sample 2 to 3 weeks previously was triturated in 2 volumes (per fresh tissue weight) of $0.2 \mathrm{M}$ sodium phosphate buffer, $\mathrm{pH} 8.0$, amended with $10 \mathrm{mM}$ EDTA and $0.15 \% \quad \beta$ mercaptoethanol, and centrifuged for 10 $\min$ at $10,000 \times g$ at $4^{\circ} \mathrm{C}$. The supernatant was filtered through a large Kimwipe, and Triton X-100 was added to $1 \%$ (vol/vol) while the extract was stirring. Polyethylene glycol (MW 8,000) was added to $4 \%$, and $\mathrm{NaCl}$ was added to a $0.2 \mathrm{M}$ final concentration while stirring. The extract was allowed to stir at $4^{\circ} \mathrm{C}$ for $2.5 \mathrm{~h}$ and then was centrifuged for $15 \mathrm{~min}$ at $10,000 \times g$. The supernatant was discarded and the pellets resuspended in approximately one-quarter of the original volume in $0.2 \mathrm{M}$ sodium phosphate buffer, $\mathrm{pH} 8.0$, overnight at $4^{\circ} \mathrm{C}$.

Triton X-100 was added to $1 \%$ (vol/vol) to the resuspended virus extract the next day, while stirring. The extract was centrifuged for $10 \mathrm{~min}$ at $10,000 \times g$ and the supernatant retained. The supernatant was centrifuged at $80,000 \times g$ for $1.5 \mathrm{~h}$, the supernatant discarded, and the pellets resuspended in $10 \mathrm{ml}$ of $0.05 \mathrm{M}$ sodium phosphate buffer, $\mathrm{pH}$ 8.0. Sucrose density gradient centrifugation was performed by layering the virus solution on top of a 10 to $40 \%$ sucrose gradient, made in $0.05 \mathrm{M}$ sodium phosphate buffer, $\mathrm{pH} 8.0$, and centrifuged at $100,000 \times g$ in a swinging bucket rotor for $2.5 \mathrm{~h}$ at $6^{\circ} \mathrm{C}$. After gradient centrifugation, any virus-containing band present in the gradient was visualized by shining a dissecting microscope light through the centrifuge tube. The virioncontaining band was removed using a glass Pasteur pipette, and diluted by addition of at least 2 volumes of $0.05 \mathrm{M}$ sodium phosphate buffer, $\mathrm{pH}$ 8.0, and pelleted by highspeed centrifugation as described above. The final pellet was resuspended in $1 \mathrm{ml}$ of $0.05 \mathrm{M}$ sodium phosphate buffer and the UV spectrum of the product analyzed using a Beckman DU-50 spectrophotometer.

cDNA cloning of the PA-4 virus. cDNA cloning of the PA-4 virus was accomplished as described previously (5). RNA was prepared from $100 \mathrm{mg}$ of $N$. benthamiana leaf tissue using a simplified nucleic acid extraction protocol (6). RNA was extracted from symptomatic plants inoculated with the PA-4 virus and uninoculated plants for use as a control. PVA-infected $N$. benthamiana, $\mathrm{PVY}^{\mathrm{O}}$ infected tobacco (both maintained at the University of Idaho), and healthy tobacco were processed using the same procedure. The final RNA pellet was resuspended in $100 \mu \mathrm{l}$ of water with diethyl pyrocarbonate (DEPC) and frozen at $-80^{\circ} \mathrm{C}$ until cDNA production. cDNA was prepared from the RNA preparations using the M4T oligo dTadapter primer described (5) using Readyto-Go cDNA beads (Amersham/Pharmacia Biotech, Piscataway, NJ). Five microliters of the crude RNA preparation and a total of $0.5 \mu \mathrm{g}$ of M4T primer were placed in a total of $33 \mu \mathrm{l}$ of DEPC-treated water and then denatured for $10 \mathrm{~min}$ at $65^{\circ} \mathrm{C}$, after which they were cooled slowly for $5 \mathrm{~min}$. The liquid was then briefly centrifuged $(10,000 \times g$ for $5 \mathrm{~s})$ and transferred to a tube containing a Ready-to-Go cDNA bead. This tube was incubated at $42^{\circ} \mathrm{C}$ for $30 \mathrm{~min}$, and then the heat block was slowly warmed until it reached a final temperature of $55^{\circ} \mathrm{C}$. The additional heating step took approximately $15 \mathrm{~min}$. Five microliters of this cDNA reaction was then subjected to polymerase chain reaction (PCR) using the $\mathrm{S}$ primer and M4 primer as described (5). After a brief denaturation at $94^{\circ} \mathrm{C}$ for 2 min, 30 cycles of PCR consisting of $30 \mathrm{~s}$ at $94^{\circ} \mathrm{C}, 1 \mathrm{~min}$ at $47^{\circ} \mathrm{C}$, and $2 \mathrm{~min}$ at $72^{\circ} \mathrm{C}$ was performed on the sample. Five microliters of each $50-\mu \mathrm{l}$ reaction was visualized using $0.8 \%$ agarose gel electrophoresis.

PCR products were cloned into the Ttailed vector pGEM-T-Easy (Promega, Madison, WI) using the manufacturer's protocol. Ligation reactions were then used to transform competent E. coli (DH10 $\beta$ ) which were plated on media containing isopropyl $\beta$-D-thiogalactopyranoside, $X$ $\mathrm{Gal}$, and Ampicillin at $100 \mu \mathrm{g} / \mathrm{ml}$. White colonies appearing the following day were analyzed for insert DNA using $0.8 \%$ TBE agarose gels (10). Colonies with apparent inserts were grown in Terrific Broth containing $100 \mu \mathrm{g} / \mathrm{ml}$ ampicillin overnight at $37^{\circ} \mathrm{C}$, and the plasmids were purified and sequenced. Dideoxy-nucleic acid sequencing was performed using an ABI 3100 Genetic Analyzer and Big Dye terminator labeled nucleic acids (V3.0). Continuous DNA sequence of inserts was determined from the sequences derived from individual reactions using the Sequence Assembly subprogram in DNAMAN DNA analysis software package (ver. 5.0, Lynnon Corp.). The consensus nucleotide sequence for the three clones was 1,905 base pairs not including the poly-A tail, and was a single open reading frame. Phylogenetic analysis was done using maximum parsimony, as implemented in PAUP (version 4.0b10) (15), using coat protein amino acid sequences. Trees were also generated using 
the neighbor-joining method, and were topologically identical to the maximum parsimony inference (data not shown). Bootstrap analysis was done on 1,000 replicates.

\section{RESULTS}

Serological assays. Initial serological analysis of PA-4 was performed by Agdia, Inc., using polyclonal assays for 16 potyviruses and the universal POTY-1 monoclonal antibody. The PA-4 samples tested negative in ELISA for all of the individual viruses, even though the company supplied positive controls all indexed as positive for their respective virus. For example, in the assay for PVV, the PA-4 sample, an optical density at $405 \mathrm{~nm}$ wavelength $\left(\mathrm{OD}_{405}\right)$ of 0.095 was observed when the positive control had an $\mathrm{OD}_{405}$ of 1.321 . The source of the polyclonal antibody in this case was DSMZ (AS0232). However, the PA-4 when positive control had an $\mathrm{OD}_{405}$ of 1.064) when assayed using the POTY1 monoclonal antibody.

ELISA performed by STA Laboratories using the BIOREBA polyclonal antibodies to PVV resulted in one slightly positive sample indexed from 30 total samples derived form PA-4 leaf tissue $\left(\mathrm{OD}_{405}=\right.$ 1.44), with healthy cut-off at $\mathrm{OD}_{405}=$ 1.431. None of the 17 samples of PA-10 leaf tissue indexed as positive for PVV. The $\mathrm{OD}_{405}$ of the positive controls were over 2.65 in all cases. ELISA of PA-4 leaf tissue performed by Phyto Diagnostics using the Agden monoclonal antibody was able to detect PVV. In this case, the $\mathrm{OD}_{405}$ of PA-4 was 0.308 , the $\mathrm{OD}_{405}$ of PA-10 leaf tissue and the company-supplied negative control were both 0.003 , and the $\mathrm{OD}_{405}$ of the company-supplied positive control was 2.234.

Host range. No symptoms developed on any plants inoculated with the PA-10 sample 14 days after inoculation. Symptom development on both plants inoculated with $\mathrm{PVY}^{\mathrm{O}}$ on tobacco, $N$. benthamiana, sample tested positive $\left(\mathrm{OD}_{405}=1.162\right.$

and the two tomato varieties was a typical mosaic as is expected for this isolate. None of the plants inoculated with extracts from the PA-4 sample showed symptoms on the two cultivars of tobacco or the two Chenopodium species, but showed mild mosaic symptoms on both assay plants of $N$. benthamiana and leaf-pucker in the two assay plants, both tomato varieties, 14 days after inoculation. No symptoms and no detection of virus infection by back-inoculation were observed in the two Datura species tested or in 'Russet Burbank' potato. In the second assay, a mild mosaic was observed in the two 'Rutgers' tomatoes and in the two PA-10 potato plants inoculated with the PA-4 virus. Infection of tomato was confirmed after back-inoculation to the two $N$. benthamiana used for each assay plant, with development of the same mild mosaic symptoms in these plants, 10 to 14 days after back-inoculation. PA-4 inoculations into the Datura species, tobacco and tomato varieties, and 'Russet Burbank' potato were repeated, and the same results, including the failure to detect infections in the Datura species, tobacco and potato assay plants, were observed in subsequent assays.

Purification of the PA-4 virus. The virus was purified to homogeneity using sucrose-density gradient centrifugation. Following sucrose-density centrifugation, a single birefringent band was visualized by shining a dissecting microscope light through the centrifuge tube. The virioncontaining band appeared at the approximate center of the tube. The purified virions had a UV spectrum of between 0.75 and $1.0 \mathrm{OD}_{260}$ units of virus that was purified from every $100 \mathrm{~g}$ of infected $N$. benthamiana leaf tissue. The $A_{260 / 280}$ ratio for purified virions was between 1.25 and 1.34. Purified virus was highly infectious when inoculated at $5 \mu \mathrm{g} / \mathrm{ml}$ onto $N$. benthamiana as described above.

cDNA cloning of the PA-4 virus. Reverse transcriptase-PCR of RNA extracts from PA-4 infected $N$. benthamiana leaf
1

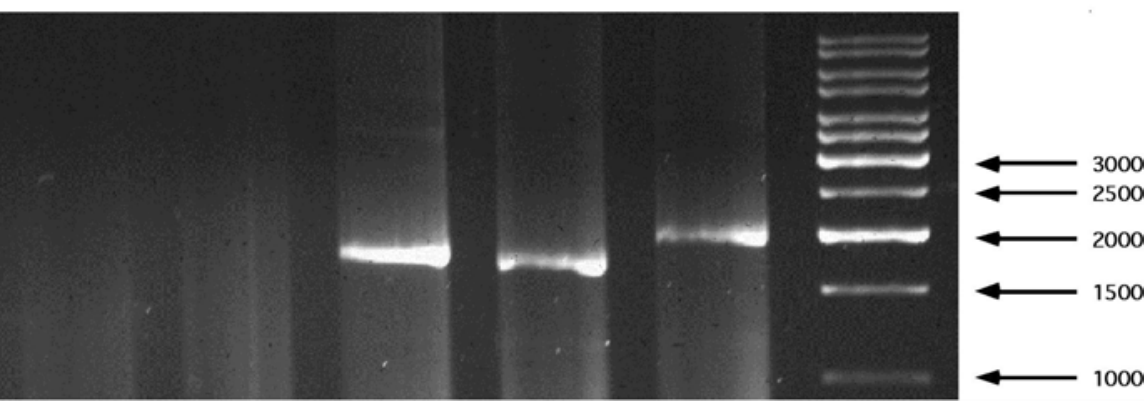

Fig. 1. Agarose gel $(0.8 \%)$ of reverse transcriptase polymerase chain reaction products from plants infected with Potato virus $Y$ (PVY), Potato virus A (PVA), or PA-4; $2.5 \mu \mathrm{l}$ of a 50- $\mu \mathrm{l}$ reaction is loaded onto each lane. Lane 1, uninoculated tobacco (Nicotiana tabacum cv. Samsun); lane 2, uninoculated $N$. benthamiana; lane 3, PVY-infected tobacco; lane 4, PVA-infected $N$. benthamiana; lane 5, PA-4 infected $N$. benthamiana; lane $6,1.5 \mu \mathrm{g}$ of a 1-kb DNA standard (Fermentis). Relative sizes of DNA fragments (in base pairs) are labeled on the right. tissue produced a single DNA band of approximately 2,000 base pairs when analyzed by gel electrophoresis (Fig. 1). In comparison, both PVY- and PVA-infected leaf tissue also gave single bands that are similar to the PA-4 generated band when amplified by this process. However, each band is distinguished by size variations. Ligation of the PA-4 reaction mixture to the PCR ready plasmid vectors produced many insert-containing plasmids. From these, three plasmids containing the fulllength inserts were sequenced so that complete sequencing of the insert in both directions was achieved. The consensus nucleotide sequence for the three clones was 1,905 base pairs not including the poly-A tail, and was a single open reading frame. All three insert sequences were identical to each other.

Initial examination of the sequence using BLAST indicated that there was highest homology to PVV. Subsequently, all available PVV sequences were obtained and compared to the PA-4 sequence. The PA-4 isolate is distinct from other PVV sequences, forming a well-supported branch intermediate between other PVV sequences and the outgroups PVY (GenBank accession M81435), PeSMV (GenBank accession X66027), and PeYMV (GenBank accession AF348610) (Fig. 2). A multiple sequence alignment of the first 50 amino acids of the coat protein cistron shows that PA-4 has a similar amino acid sequence to the published PVV sequences available through GenBank. However, PA4 has a higher level of substitutions in this than the consensus of the other accessions (Fig. 3).

\section{DISCUSSION}

Our data indicate that the PA-4 isolate is distinguishable from other isolates of PVV. It escapes serological detection using commercially available reagents, and thus is a cause for concern for seed certification and international germ plasm movement. Indexing of this isolate by ELISA using two commercially available polyclonal antibodies failed to detect PVV to any significant degree. Assays using the Agden monoclonal antibody to PVV were able to detect PA-4, but at an OD seven times less than the positive control. The universal POTY-1 monoclonal antibody was able to detect potyviruses at a level consistent with a systemic infection of a plant with a potyvirus.

Amino acid alignment of PVV coat protein sequences suggests that the reason for lack of serological detection in the polyclonal antibody based assays is due to amino acid substitutions in the first 50 amino acids of the coat protein (CP) (Fig. 3 ). There are other substitutions in PA-4 and other PVV isolates scattered throughout the CP sequence that occur at a lower frequency. However, considering that the amino terminus of the coat protein has 
been determined to be on the exterior surface of the virion in potyviruses, this is the likely location of an altered epitope(s) (14). This region is the location of the majority of amino acid substitutions in PA-4.

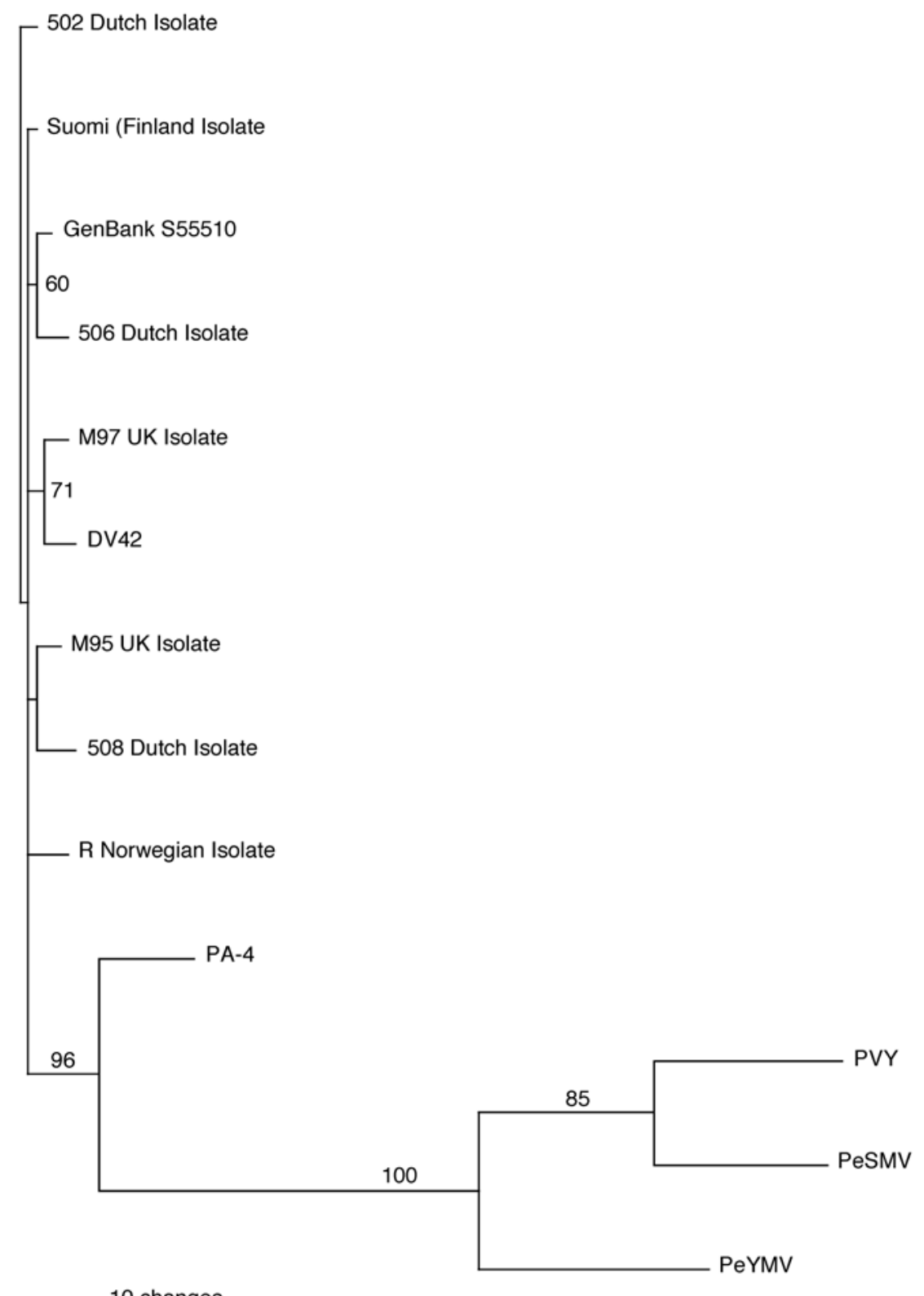

Fig. 2. Phylogenetic tree of Potato virus $V$ coat protein amino acid sequences, based on an inference using maximum parsimony. Numbers at some branches are percent bootstrap support for values $>60 \%$. This is a rooted tree, with Pepper severe mosaic virus (PeSMV), Pepper yellow mosaic virus (PeYMV), and Potato virus $Y$ (PVY) as outgroups.
Currently, there is limited biological information on the host range and symptomology of PVV. Brunt and Loebenstein (3) described the host range as limited to the Solanaceae and confined to the genera
Solanum, Lycopersicon, and Nicotiana, where symptoms ranged from symptomless in some potato cultivars to veinal necrosis in Solanum demissum $\times S$. tuberosum 'Aquila', A6. The PA-4 virus exhibits a similar host range and symptomology to that described for PVV, except that it does not appear to infect the tobacco varieties tested (Xanthi and Burley 21), tobacco being listed as an experimental host (3). In addition, this report indicates that several potato varieties were susceptible and produced symptoms ranging from symptomless infection to local necrotic spots. These cultivars include Wauseon, Foxton, Estima, Desiree, Maris Poper, and Pentland Crown, varieties which are commonly grown in Europe. We have been unable to detect infection in 'Russet Burbank' potato, after several attempts, but have been able to reinfect virus-free 'Papa Amarillo'. Based on the biological and molecular characteristics of this virus, we conclude that the PA-4 isolate is a previously undescribed serological strain of PVV (PVV-PA4). Production of a polyclonal antibody to this new isolate is currently underway to provide a complete characterization and comparative analysis of its serological properties.

\section{LITERATURE CITED}

1. Berger, P. H., and Shiel, P. J. 1998. Potyvirus isolation and RNA extraction. Pages 151-160 in: Plant Virology Protocols. G. D. Foster and S. C. Taylor, eds. Humana Press Inc., Totowa, NJ.

2. Brunt, A. A., Crabtree, K., Dallwitz, M. J. Gibbs, A. J., and Watson, L. 1996. Viruses of Plants. Descriptions and Lists from the VIDE Database. CAB International, Cambridge, UK.

3. Brunt, A. A., and Loebenstein, G. 2001. The main viruses infecting potato crops. Pages 65 134 in: Virus and Virus-like Diseases of Potatoes and Production of Seed-Potatoes. G. Loebenstein, P. H. Berger, A. A. Brunt, and R. H. Lawson, eds. Kluwer Academic Publishers, Dordrecht, Netherlands.

4. Calvert, E. L., Cooper, P., and McClure, J. 1980. An aphid-transmitted strain of PVYC ${ }^{C}$ corded in potatoes in Northern Ireland. Rec. Agric. Res. Dep. Agric. Northern Ireland 28:63-74.

5. Chen, J., Chen, J., and Adams, M. J. 2001. A universal PCR primer to detect members of the Potyviridae and its use to examine the taxonomic status of several members of the family. Arch. Virol. 146:757-766.

6. Dellaporta, S. L., Wood, J., and Hicks, J. B. 1983. A plant DNA minipreparation: Version II. Plant Mol. Biol. Rep. 4:19-21.

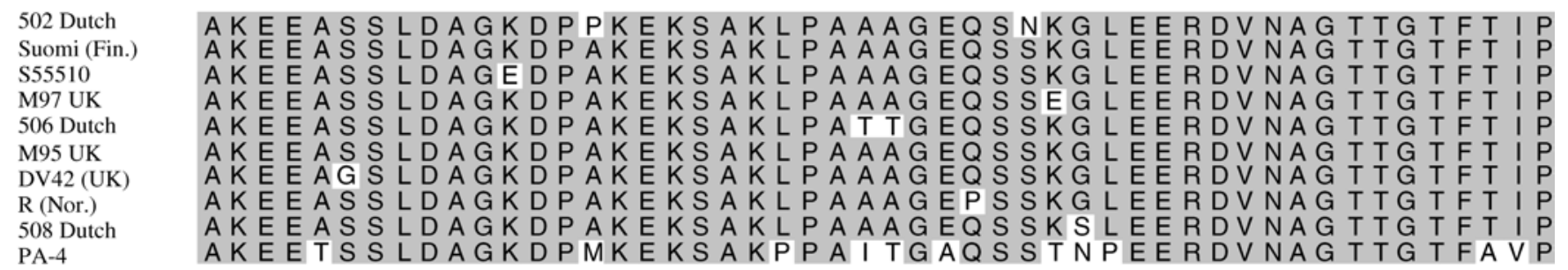

Fig. 3. Alignment of the first 50 amino acids of coat proteins of isolates of Potato virus $V$. Shaded amino acid residues are identical at each position. GenBank accessions for each entry are as follows: 502 Dutch, AJ253119; Suomi (Fin.), AJ278854; S55510, S55510; M97 UK, AJ253123; 506 Dutch, AJ253120; M95 UK, AJ 253122; DV42 (UK), AJ243766; R (Nor.), AJ253124; 508 Dutch, AJ253121; and PA-4, XX000000 (this report). 
7. Fernandez-Northcote, E. N. 1986. Peru tomato virus. ISHS Vegetable Virus Working Group Newsl. 14:13-14

8. Fribourg, C. E., and Nakashima, J. 1984. Characterization of a new potyvirus from potato. Phytopathology 74:1363-1369.

9. Jordan, R., and Hammond, J. 1991. Comparison and differentiation of potyvirus isolates and identification of strain-, virus-, subgroupspecific and potyvirus group-common epitopes using monoclonal antibodies. J. Gen. Virol. 72:25-36.

10. Le Gouill, C., and Dery, C. V. 1991. A rapid procedure for the screening of recombinant plasmids. Nucleic Acids Res. 19:6655.

11. Oruetxebarria, I., and Valkonen, J. P. 2001 Analysis of the P1 gene sequences and the $3^{\prime}$ terminal sequences and secondary structures of the single-stranded RNA genome of Potato virus V. Virus Genes 22:335-343.

12. Rozendaal, A., van Binsbergen, J., Anema, B., van Slogteren, D. H. M., and Bunt, M. H. 1971. Serology of a deviating potato virus $\mathrm{Y}$ strain in the potato variety Gladblaadje. Potato Res. 14:141.

13. Sanchez, G. E., Slack, S. A., and Dodds, J. H.
1991. Response of selected Solanum species to virus eradication therapy. Am. Potato J. 68:299-315.

14. Shukla, D. D., Strike, P. M., Tracy, S. L. Gough, K. H., and Ward, C. W. 1988. The N and $\mathrm{C}$ termini of the coat proteins of potyviruses are surface-located and the $\mathrm{N}$ terminus contains the major virus-specific epitopes. J. Gen. Virol. 69:1497-1508.

15. Swofford, D. L. 2002. PAUP*:Phylogenetic Analysis Using Parsimony (*and Other Methods), Version 4. Sinauer Associates, Sunderland, MA. 